\title{
CLASSICAL AND CROSS INSIDER TRADING: VARIATIONS ON THE THEME OF RULE 10b-5
}

*NICHOLAS L. GEORGAKOPOULOS

\section{INTRODUCTION}

In recent years there has been intense enforcement and scrutiny of the insider trading laws. It is still advisable, however, to examine the insider trading rules for their coherence and consistency. This article only explores the insider trading rules as they apply to trading by traditional insiders - the management team and its temporary members from the professional ranks such as bankers, lawyers, and accountants - all of whom owe fiduciary duties to the employer corporation and its shareholders.

The purpose of this article is to uncover an inconsistency in the reasoning behind insider trading regulation of this traditional group. ${ }^{1}$

* S.J.D. candidate, Harvard Law School. Member, New York Bar. I would like to express my gratitude to Professor Reinier Kraakman of the Harvard Law School for his invaluable help in the supervision of my dissertation, to which this article is related. I would also like to express my gratitude to Giddeon Shor, Matthew Kreeger, Alan Nadelhaft, and Bryan Askew.

${ }_{1}$ Quite different policy considerations are involved in the issue of tipper/tippee liability: the efficient dissemination of information, its value to market participants, and the role of investment analysts. Thus, the issue of tipper/tippee liability should be addressed separately. See Dirks v. SEC, 463 U.S. 646 (1983). See generally D.G. LANGEvoort, Insider Trading Regulation (1988); H. ManNe, Insider Trading and the Stock MARKET (1966); Carlton \& Fischel, The Regulation of Insider Trading, 35 STAN. L. REv. 857 (1983); Haft, The Effect of Insider Trading Rulas on tho Internal Efficicusy of the Large Corporation, 80 Mich. L. REv. 1051 (1982); Wang, Trading on Material Nonpublic Information on Impersonal Stock Marlosts: Who is Harmod and Who Can Sue Whom under SEC Rule 10b-5?, 54 S. CAL. L. REv. 1217 (1981). 
The present regulations address the fiduciaries' trading in the stock of corporations to whom a fiduciary duty is owed. Trading on the basis of inside information in stock of entities with which the trader has no fiduciary relationship is not proscribed. To illustrate, if the management of corporation $A$ knows that $A$ will offer to enter into a contract with corporation B, thereby greatly enhancing B's value, members of A's management team are free to trade in B's stock based on this "inside" information because they owe no fiduciary duties to B's shareholders. This article will examine this phenomenon and will assess the desirability of this form of trading, which will be called cross trading, connoting insider trading that crosses corporate boundaries. ${ }^{2}$ The traditional form of insider trading will be referred to as classical insider trading.

The first federal proscription on insider trading was section 16 of the Securities Exchange Act of $1934 .^{3}$ The persons regulated by section 16 often are referred to as statutory insiders; they must adhere to the requirements of section 16, which, among other things, require them to disclose transactions to the Securities and Exchange Commission. Classical insider trading also breaches the primary proscription against insider trading under Rule $10 \mathrm{~b}-5^{4}$ as construed by the United States Supreme Court in Chiarella $v$. United States. ${ }^{5}$ This proscription is based on the theory that insiders buying or selling stock of their corporation without disclosing that inside information breach their fiduciary duty to disclose, which they owe to shareholders. The traders' nondisclosure in violation of the duty to disclose and their subsequent trading amount to a fraud violating Rule 10b-5.

The status of cross insider trading under Rule $10 \mathrm{~b}-5$ is ambiguous. After Carpenter $v$. United States, ${ }^{6}$ a person who engages in cross insider trading risks prosecution under the misappropriation theory of Rule 10b-5. Criminal liability may also arise under the federal mail and wire fraud statutes. ${ }^{7}$ The misappropriation theory is an

2 The term "outsider trading" is used more often. See, e.g., Aldave, Misappropriation: A General Theory for Trading on Nonpublic Information, 13 HoFsTRA L. REv. 101, 112 (1984) (citing Freeman, The Insider Trading Sanctions Bill-A Neglected Opportunity, 4 PACE L. REv. 221 (1984)). See also Bagby, Outsider Misappropriation: Carpenter v. United States, 16 SEC. REG. L.J. 204 (1988). "Cross insider trading" will be used to distinguish this trading from the universe of outsiders and to emphasize that cross insider trading is just a variation of insider trading.

315 U.S.C. $\$ 78 \mathrm{p}$ (1988). The first instance of state proseription of insider trading arose in Strong v. Repide, 213 U.S. 419 (1909).

417 C.F.R. $\$ 240.10 b-5$ (1988).

5445 U.S. 222 (1980).

6 484 U.S. 19 (1987).

718 U.S.C. $\$ 1341$ (1988) (mail fraud); id. $₫ 1343$ (wire, radio, and television fraud). 
interpretation of Rule $10 \mathrm{~b}-5$ intended to reach cross insider trading by arguing that a trader's use for profit of information "misappropriated" from another entity, such as the corporation where the trader is employed, amounts to a fraud against the employer, violating Rule 10b-5. In spite of these efforts against cross trading, one could argue that the crosstraders' actions are less central to the concerns of the securities laws than classical insider trading. The peculiar split of the Court in Carpenter $^{8}$ lends credence to this position. This article intends to show, however, that cross insider trading is more undesirable than its classical counterpart, given the balance of policy concerns underlying the regulation of insider trading.

The first part of this article reviews the intense scholarly debate over classical insider trading, which was identified and prohibited long before cross trading. Indeed, cross insider trading rules could develop only after the classical form was defined to exclude cross trading transactions, which happened in Chiarella. This part will also introduce an analysis of the shareholder injury attributed to insider trading using the fraud-on-the-market theory. The article's second part discusses the compelling policy considerations justifying the prohibition of cross insider trading. In conclusion, suggestions are made for improvements on the insider trading regulatory scheme.

Classical Insider Trading

\section{Background}

The history of insider trading's proscription closely follows the history of interpreting Rule 10b-5. Only recently has the Securities and Exchange Commission expanded the source of the proscription by adopting more rules, such as the tender offer insider trading Rule $14 \mathrm{e}-3 .{ }^{9}$

The SEC's regulation of insider trading as a form of fraud violating Rule 10b-5 began with In re Cady, Roberts \& Co. ${ }^{10}$ The Second Circuit embraced the SEC's view in SEC $v$. Texas Gulf Sulphur

- See infra notes $82-91$ and accompanying text.

917 C.F.R. $\$ 240.14 \mathrm{e}-3$ (1988).

1040 S.E.C. 907 (1961). There, a member of a securities firm managing discretionary accounts sold stock on behalf of all the accounts upon receipt of inside information. The "disclose or abstain" theory was introduced in a disciplinary action against the manager: "IInsiders must disclose material facts which are known to them by virtue of their position but which are not known to persons with whom they deal and which, if known, would affect their investment judgment. Failure to make disclosure in these circumstances constitutes a violation of the anti-fraud provisions. If ... disclosure ... would be improper. ... the alternative is to forego the transaction." Id. at 911. 
Co., ${ }^{11}$ accepting the "disclose or abstain [from trading on material nonpublic information]" interpretation of 10b-5. Chiarella, however, established that the breach of a duty to disclose is necessary for a 10b-5 fraud. ${ }^{12}$ There, Chiarella, a financial printer for the acquiring corporation in a merger, was convicted for trading in stock of the target corporations. But he was exonerated by the Supreme Court because, being employed by the acquirer, he had no duty to disclose this information to the target's shareholders. The Court thus limited the "disclose or abstain" rule to cases in which trading breaches a fiduciary duty (to disclose the inside information) owed to fellow shareholders on the other side of the transaction.

Chiarella came as a shock to the SEC, because the Court overturned a conviction for what was then the most patently unfair form of insider trading. The SEC responded by promulgating Rule $14 \mathrm{e}-3,{ }^{13}$ which forbids all trading on information about impending mergers. Thereafter, the SEC pursued a different interpretation of Rule $10 \mathrm{~b}-5$, the misappropriation theory, in order to overcome the limitations of Chiarella in areas that Rule $14 \mathrm{e}-3$ would not reach.

Meanwhile, a seemingly unrelated aspect of Rule $10 \mathrm{~b}-5$ arose. The courts interpreted Rule $10 \mathrm{~b}-5$ to mandate public disclosure of merger negotiations. Neither this facet of $10 \mathrm{~b}-5$, nor insider trading law generally, is yet crystallized. The participants in the merger or other business combination must avoid making any statements or omissions that amount to "material misrepresentations" because by doing so they would be perpetrating a fraud violating Rule $10 \mathrm{~b}-5$ upon all those who traded at prices affected by the misrepresentations. In other words, management has a duty not to mislead investors transacting in the company's shares about their value.

It is interesting to note that the two aspects of Rule $10 \mathrm{~b}-5$ interpretation, the insider trading proscription and the disclosure mandate, have followed quite different roads. For the sake of consistency and clarity, there should be an effort at unifying the two approaches. The policy debate on classical insider trading regulation should provide insight into the necessity and extent of its prohibi-

${ }^{11} 401$ F.2d 833 (2d Cir. 1968). In Texas Gulf Sulphur, employees traded on their inside information about their corporation's major copper ore strike. In an en banc decision, the Second Circuit found for the SEC, embracing the "disclose or abstain" theory. "[A]nyone in possession of material inside information must either disclose it to the investing public, or, ... must abstain from trading ...." Id. at 848.

${ }_{12}$ "Thus, administrative and judicial interpretations have established that silence in connection with the purchase or sale of securities may operate as a fraud actionable under $\oint 10(\mathrm{~b})$.... But such liability is premised upon a duty to disclose arising from a relationship of trust and confidence between parties to a transaction." 445 U.S. at 230.

13 See supra note 9 and accompanying text. 
tion. And the fact that this prohibition is mandatory, that a corporation cannot choose to avoid the proscription of insider trading, also should inform the policy debate.

Insider trading encompasses forms too mild to be prohibited and others so unfair that they do not require any further express prohibition beyond the general fraud rules. At the mild end of the spectrum is trading by statutory insiders who earn returns higher than the average market participant ${ }^{14}$ by trading on the softest nonpublic information - their expectations for the future, which are not sufficiently material to violate the prohibition on insider trading. At the other end of the spectrum is the fiduciary who actually sells confidential factual information. By deriving personal profit from the disclosure of confidential information, the manager/agent violates basic principles of agency law. ${ }^{15}$ The question is not whether, but to what extent, to ban insider trading. At which point on this spectrum should the line be drawn?

The relevant policy considerations must also justify the mandatory character of the prohibition on insider trading. For example, arguments that emphasize insider trading's effects on the shareholders of a particular firm (firm-specific arguments) fail this test, because individual firms should be expected to prohibit it themselves if they are harmed. ${ }^{16}$

Shareholder Injury

The first issue to explore is the potential for direct pecuniary harm to investors by the insiders. A less direct kind of injury introduced by Professor Wang also will be examined. According to Wang, insider trading leaves the "wrong" amount of stock in the hands of the public - less on a price rise and more on a price dropand this indicates that outside shareholders are disadvantaged by insider trading. ${ }^{17}$

\footnotetext{
${ }^{14}$ See generally Carney, Sigmaling and Causation in Insider Trading, 36 CATH. U.L. REv. 863, 879 (1987) (citing, inter alia, Basel \& Stein, The Value of Information: Some Inferences from the Probability of Insider Trading, 14 J. Fin. \& QUANT. ANALYsis 553, 567-69 (1979); Finnerty, Insiders and Market Efficiency, 31 J. FIN. 1141, 1142 (1976)).

${ }_{13}$ See generally Restatement (Second) of Agency $\$ 395$ (1958); Strong v. Repide, 213 U.S. 419 (1909); Goodwin v. Agassiz, 283 Mass. 358, 186 N.E. 659 (1933); Diamond v. Oreamuno, 24 N.Y.2d 494, 301 N.Y.S.2d 78, 248 N.E.2d 910 (1969).

${ }^{18}$ See, e.g., Bebchuck, Limiting Contractual Freedom in Corporate Law: The Desirable Constraints on Charter Amendments, 102 HARV. L. REv. 1820 (1989); Easterbrook \& Fischel, Mandatory Disclosure and the Protection of Investors, 70 VA. L. REv. 670 (1984) (questioning the disclosure provisions of the securities laws). But see F. Easterbrook \& D. Fischel, The Economic Structure of Corporate Law (1986) (draft from chapter of a prospective book) (advocating no mandatory provisions in corporate law).

${ }^{17}$ Wang, supra note 1 , at 1234 .
} 


\section{Injury Under Basic: Fraud on the Market}

In Basic, Inc. $v$. Levinson, the Supreme Court went a long way toward including in its legal analysis the latest theory of market mechanics. ${ }^{18}$ The same analytical tools used implicitly in Basic, the Capital Asset Pricing Model (hereinafter CAPM) and the Efficient Capital Markets Hypothesis (hereinafter ECMH), illustrate the injury caused by insider trading.

The ECMH and CAPM claim that market price is not a result of supply and demand but of the risks and expectations the market assigns to each stock. All other things being equal, stocks with the same volatility rate or risk, often noted as the stock's "beta," are perfect substitutes, and investors will not prefer one to the other. A minute change in price, if it is not related to a change in the expected return from the stock, will drive the market participants to take advantage of what they sec as mispricing. As soon as price rises with no explanation, investors will take their profits and purchase more of the still-cheap stock of other corporations with the same beta. The CAPM predicts the opposite when the stock price drops. This leads to a large elasticity of supply and to an almost infinite supply at a price level slightly above the previous equilibrium. ${ }^{19}$

Thus, information that would alter expectations is the most important determinant of price, while the effects of supply and demand

${ }^{18}$ Basic, Inc. v. Levinson, 485 U.S. 224 (1988) (unanimously affirming a conviction for mail and wire fraud but splitting 4.4 on the securities fraud violations). In Basic, the Court accepted a variation of "fraud on the market" theory, id. at 990-91, 993 ("It is not inappropriate to apply a presumption of reliance supported by the fraud-on-the-market theory."). There are two variations of fraud-on-the-market: (1) the variation creating a rebuttable presumption of relianec on the misrepresentation that eauses the price to bo at the level it assumes (the form accepted by Basic); and (2) a stronger variation that conclusively presumes causation, claiming that trading at misinformed prices is tanta mount to being defrauded. The Basic Court did not aecept this latter formulation. The practical importaneo of the distinetion is lessened by the fact that rebuttal of the presumption of relianee in the former version is very diffieult. Additionally, because robuttal consists to a large extent of nogating the officiency of capital markets (when it talses the form that the marlset was not affected by the misrepresentation and thus did not "rely"), to that extent it is identical to negating the prerequisites for the application of the fraud on-the-market thoory, which is founded on the assumption that capital markets are efficient (i.e., that prices reflect all public information).

19 This hypothesis is confirmed by empirical data. For example, Edper Enterprises bought $25 \%$ of Brasean Limited on the marlset with minor price movement. Then, after a pross release disavowing its intent to take over Brasean, Edper managed to accumulate over $50 \%$ of the stock without significant price movement. Soc Carncy aupra note 11, at 888, 889-90, citing Brascan Ltd. v. Edper Equities Ltd., [1979 Transfer Binder] Fed. Sec. L. Rep. (CCH) \96,882, at 95,617, 95,618-25 (S.D.N.Y. 1979). 
(or volume effects) are only secondary determinants of market price. ${ }^{20}$ The CAPM model suggests that insider trading affects stock prices through expectations, not through supply and demand.

Insider trading detected by the markets will itself affect share price because it is one more piece of information for market participants. ${ }^{21}$ There are three possible connections between the detection of insider trading and stock price changes: (1) insider trading may go undetected, causing little or no price change, (2) it may be detected and have the same effect on the price as full disclosure, or (3) it may be detected but have a muted effect on price.

No Effect on Price. If the market price is not affected by insider trading, the insider's trade does not cause the outsider's trading on tho opposito side. As Carney oxplains, if the buy orders of insiders cannot be met by sellers on the market, then market makers or specialists are forced to trade, not the investors. ${ }^{22}$ Carney proceeds to note that if insider trading is costly to the market makers, they should be expected to harmlessly adjust the bid/ask spread in order to account for the expense. It should be observed, however, that this effect would not be harmless, because it would increase transaction costs at the expense of other investors and of market liquidity.

Individual investors, however, are the least hurt by this extra transaction cost generated by insider trading. Professionals, not lay investors, account for most of the trading volume and they suffer the most from transaction costs. In addition, Carney argues that individual investors would rather allocate the right to trade on

${ }^{20}$ Even without accepting the modern portfolio theory (ECMH and CAPM), information remaine a most important mover of share prices. Investors probably accept the current market price as reflecting the current value of the firm, and each new bit of information tende to move price accordingly. If modern portfolio theory is not accepted; then supply and demand still affect price. In such a case, even undisclosed inside trading will have some effect on prices bocause it would move prices upward by inereasing demand or downward by increasing supply. The effect of information, however, is not lessened.

${ }^{21}$ Gilson \& Kraakman, The Mechanisms of Market Efficiency, 70 VA. L. REv. 549, 62932 (1984) ("[T]he price effect of incider trading is an example of what we have called derivatively informed trading mechanism. As a result of price or trade decodingdeducing the content of private information from transitory price fluctuations or the identity of traders - the market 'learns' the relevance of the insider's private information from their own trading activity, and the prieo of the security changes to reflect the market's new information."). For example, a sudden rise in the trading volume of a prime takeover candidate suggeete to the market that private information probably drives this activity. The market will price accordingly.

22 Carney, supra note 14, at 888-89. 
inside information to insiders, who might then accept lower pay. ${ }^{23}$ This argument will be considered again. ${ }^{24}$ In sum, the effects of insider trading that leaves price unaffected do not seem to indicate injury to shareholders.

Next we consider a form of injury involving misrepresentation: that the insiders trade on secret information, thereby defrauding sharcholders who unknowingly trade at wrong prices. In Basic, Inc. $v$. Levinson, ${ }^{25}$ the Supreme Court observed, in the context of disclosing merger negotiations, that "misleading statements ... defraud purchasers of stock even if they do not directly rely on the misstatements," ${ }^{26}$ because they trade at a fraudulent price. From here it is only a short step to saying that the failure to disclose matorial information in the context of insider trading similarly defrauds all those who trade on the fraudulent market price. ${ }^{27}$ If so, then all insider trading constitutes a fraud on all those trading contemporaneously opposite insiders. The crucial element, however, would not be insider trading per se but the nondisclosure of material information. ${ }^{28}$ Such nondisclosure leads to mispricing, which yields fraud on the market.

The weak link in this legal syllogism is the disclosure requirement imposed on the insiders. Unless there is such a disclosure requirement, the insiders' nondisclosure will be lawful. If there is no duty to disclose, there can be no liability for the resulting mispricing. But since the above analysis concerns classical insider trading, even an analysis limited by the requirement of a duty to disclose based on a fiduciary relationship will suffice to yield a proscription, because such a relationship exists between the classical insider and the shareholders. Fiduciaries have been held to have a duty to

${ }^{23}$ See Carney, supra note 14, at 897. See also Haddock \& Macey, $A$ Coasian Model of Insider Trading, 80 Nw. U.L. REv. 1449, $1478-79$ (1986); infra text accompanying notes 54-56.

${ }^{24}$ See infra text accompanying notes 54-56. The opposite argument can also be made: the general public participates in the market, not by direct stock ownership, but principally through institutions such as ponsion funds, life insurance, and mutual funds. The public should want its investments, not the insiders, to benefit from the ban on insider trading. Research comparing the two schemes is needed. The fundholder would likely prefer a direct fund bencfit to unregulated insider trading.

${ }^{25} 485$ U.S. 224 (1988).

${ }_{23}^{2} I d$. (quoting Peil v. Speiser, 806 F.2d 1154, 1160-61 (3d Cir. 1986)).

${ }^{27}$ See supra note 18.

${ }^{28}$ If the price of the stock reaches the same level it would have reached after a disclosure, then there would bo no injury. The prieo is not artificially inflated as if by misstatement, but reflects actual developments. There are other considerations mainly associatcd with the traders on the same side as the insider; these will be discussed infra at the text accompanying notes 29-30. 
"disclose or abstain from trading." ${ }^{29}$ Notice that injury from insider trading is found here by using Rule $10 \mathrm{~b}-5$ in a way that it is not traditionally used in insider trading cases.

Full Price Rise. If insider trading causes share prices to rise to the level they would have reached had there been full disclosure, two aspects of injury would have to be examined: the possible injury to investors who traded opposite the insider, and the possible injury to those trading on the same side with the insider. Investors trading opposite the insider do not seem to be worse off. On the contrary, they get the payoff of their investment sooner than if they had waited for the information to become public in the usual ways. They have the double benefits of interest payments on their cash and an carlier end to their exposure to market risks. Otherwise, they would have had to wait for a disclosure that would result in the same price movement in order to liquidate their positions.

Paradoxically, the investor who trades on the same side as the insider will have a stronger claim of injury, because he buys a security at a price that already is high. If it is publicly known that insiders have traded, the securities buyer should also know that the price may be elevated, because news whose announcement he is anticipating might already be reflected in current market price through insider trading. The investor trades, nevertheless, because he assumes that the price still will move favorably. Either insider trading did not move price all the way to the level it would reach after disclosurc, or the insider trading was motivated by information different from the information on which the investor based his trades.

If, by contrast, the investor is not aware of insider trading, then the investor can claim to be deprived of the profits otherwise attainable. This investor has assumed the risk of owning a specific stock in order to profit from his analysis. The elevated price at which such an investor traded was a result of insider trading. The purchaser is injured by not being informed that the recent price rise is attributable to insider trading. This injury is fraudulent because this insider trading involves material information which the insidors must disclose due to their fiduciary link to the sharcholders.

Once injury is established, the injured investor need not establish relianee on the misrepresentation. Basic suggests that it is possible to presume reliance through "fraud on the market." This means that the investor (a market participant to whom the insider is linked

${ }^{29}$ See, e.g., Chiarella v. United States, 445 U.S. 222, 227 (1980) ("a corporate insider must abstain from trading ... unless he has first disclosed ...."). 
by a fiduciary bond) relicd on the misinformation by trading at an artificial market price. ${ }^{30}$

Partial Price Rise. In the third case, the stock price does not rise to the level it would reach with full disclosure. In this situation, the analysis for investors trading on the same side with the insiders will not differ from the analysis presented above. Therefore, it is only necessary to focus on the insiders' counterpartics.

Here, investors who traded opposite the insiders are better off than they would have been had no insider trading occurred. If the information is material (which presumably is the case if it causes the stock price to rise ${ }^{31}$ ), the investors will be allowed to claim the extra profit they would have enjoyed with full disclosure, using a line of reasoning similar to that employed above for the case of no price movement. Investors invoking the "fraud on the market" theory need not prove that they relied on the insider's misrepresentation, because reliance is presumed. Furthermore, investors' knowledge that insider trading eaused the price rise docs not affect the reasoning in this case. Their loss is the difference between the prico at which they sold and the price after disclosure. Even if the investors know that insider trading caused the price rise, they will not necessarily expect further price movement. For investors to expect this, one would have to argue that the mere existence of insider trading should warn traders of further volatility. Arguably, the current price represents discounting by the market for the uncertain message contained in insider trading, and the fact that in practice it might take a long time for the markets to reach an accurate price, in which case investors may be presumed to be warned of further volatility when insiders are trading. This line of reasoning, however, is much too complex to be imputed to investors and used to erode their legal protection.

The search for a tort-like injury caused by insider trading led to Rule 10b-5 and its disclosure requirements, the sources of the "fraud on the market" theory. One hopes that both aspects of Rule 10b-5 form one coherent theory. In the above analyses, however, nondisclosure played a crucial role in linking insider trading to injury. This suggests that specdicr disclosure requirements might diminish

${ }^{30}$ This reasoning is based, of course, on several assumptions: nondisclosure of material information; trading by insiders; and a price rise caused by the informational cffect of incider trading, while this trading is not known to the public. This information, however, usually will be considered material since the test for materiality - whether a reasonable shareholder would consider the information important ... is casily passed. See TSC Indus. v. Northway, 426 U.S. 438 (1976); Basic, Inc. v. Levinson, 485 U.S. 224 (1988).

${ }^{31}$ See supra note 30 . 
the harm from insider trading by disseminating the news of such trading, which will cause quicker and more accurate pricing.

In sum, the CAPM and "fraud on the market" theories form the analytical basis used to consider how insider trading causes injury to investors. These theories suggest that insider trading is undesirable; its undesirability, however, stems not from insider trading as such, but from its secret nature.

\section{Wang's View: Insider Trading Causes Redistribution of Price Moves in Favor of Insiders}

Professor Wang ${ }^{32}$ explains that insider trading causes less stock to be held by the public on a price rise and more on a price drop. He argues that insiders act in anticipation of the price movement by adjusting their holdings. The result is that insiders hold comparatively more of the stock on price rises and less on price falls. Consequently, the returns of stock price movements are unevenly redistributed from investors to insiders. Although Wang's view is plausible, it is hard to assess. Since insider trading accounts for a minuscule fraction of the overall trading volume, ${ }^{33}$ it is unlikely that insiders' trades cause any major redistribution of the stock and its returns from outsiders to insiders. This harmful effect consists of an injury to the shareholders, based on the statistically supported assumption that insiders usually trade on correct predictions. Any specific insider trading transaction, however, does not necessarily belong to the group of trades made on correct predictions and thus might not have this effect. Due to this loose causal connection between trading and its harm, the Wang view is not a compelling argument for proscribing insider trading. It does, however, indicate a harmful effect of insider trading which has to be taken into account in order to determine whether a proscription of insider trading is warranted.

\section{Market Efficiency}

It is also important to consider the effect of insider trading on market efficiency. The proper inquiry is whether insider trading

${ }^{32}$ Wang, supra note 1 , at 1234 .

"Heller, Chiarella, S.E.C. Rule 14 e-3 and Dirks: "Faimess" versus Economic Theory, 37 Bug: LAW. 517, 556 (1982) (mentioning that insider trading amounts to "a tiny fraction of one percent of the volume of trading," quoting the Chairman of the SEC at a then recent interview, N.Y. Times, Oct. 26, 1981, at D1). The Chairman may have changed his mind after the Boesky affair. It is, however, unlikely that the "tiny fraction of ono percent" need be revised greatly upward. In addition, the Boesky affair included crosstrading and tipper-tippee issues which do not affect the reasoning here. 
enhances market efficiency and is therefore desirable. Two main arguments connect market efficiency with insider trading. ${ }^{34}$ The first stipulates that insider trading adjusts share prices towards their "true" level, enhancing market efficiency. It will be shown that this view is mistaken given the current regulation of insider trading, although it could be valid were that regulation amended to require speedier disclosure. The second argument is that the freedom to engage in insider trading induces managers to release information to the market. Although commentators take different positions on this issue, it will be suggested that insider trading does accelerate the flow of information to the markets. Finally, upon comparison of insider trading with stock options, it will bc submittcd that options do not induce as great an acceleration in the flow of information as insider trading.

\section{Price Efficiency}

If insider trading drives prices towards their "true" level, it promotes market efficiency. The traditional view has been that insider trading performs this function through supply and demand. Modern finance theory, by contrast, holds that price movements depend more on information than on supply and demand,,$^{35}$ although

${ }^{34}$ The necessity of efficient markets might not be so obvious. However, efficient markets induce efficient allocation of capital rcsources. Capital markets cxist to cnable cerporations to iseuo securitics and thercby raise money for corporatc purposes. Estab lishing the "right" prices for securities benefits society by allocating the "right" amount of capital to each firm, so that the most capital goes to the best user of it, and the least to the worst.

Further, when securities prices reflect the "true" value of the underlying securities, the risk of owning securities is much less than in an inefficient market because the value of the securitios will bear a constant relationship to the rcal value of the underlying security. This will reduce the risk of owning securities, which will make investors value securities more highly and will reduce the cost of capital to issucrs, since securitics will command higher prices. The virtues of efficient capital markets are described in Lorie, Insider Trading: Rule 10b.5, Disclosurc, and Corporatc Privacy: A Comment, 9 J. LEGAL STUD. 819 (1980). See also Kahan, Normative Aspects of Stock Market Efficiency (research papcr). Cf. Stout, The Unimportance of Being Effieient: An Economi Anulysis of Stuch Market Pricing and Securities Regulation. 87 MICH. L. REv. 613 (1988).

Efficiont markets also help talicovers worls efficiently. If market prices are erratic, acquirers face additional risk; low prices will induce excess takeover activity, while high prices will inhibit useful takeovers and entrench ineffieient management. See Kraakman, Talcing Discounts Seriously: The Impliations of "Discounted" Sturie Prives us un Acyui sition Motive, 88 CoLUM. L. REv. 891 (1988).

${ }^{35}$ See Carney, supra note 14, at 889-90 (referring to Scholes, The Market For Securities: Substitution Versus Price Pressure and the Effects of Information on Share Prices, $45 \mathrm{~J}$. Bus. 179 (1972)). See also Easterbrook, Insider Trading, Secret Agents, Evidentiary Privileges, and The Production of Information, 1981 SuP. CT. REv. 309, 336; Gilson \& Kraakman, supra note 21, at 629-34. 
the two are not always easy to distinguish. Consequently, insider trading does not by itself drive prices to their correct level and does not enhance market efficiency. Efficiency, therefore, can only be enhanced through the informational effect of insider tradingthrough the effect of public knowledge or suspicion of such trading. Secret insider trading will not affect prices. ${ }^{36}$

Section 16(a) of the $1934 \mathrm{Act}^{37}$ requires that statutory insiders report all changes in their equity stock holdings (effectively, their trades) by the tenth of the next month. This rule leaves a period of ten to forty days for reporting-far from an effective way to disseminate information to today's markets. Were the reporting concurrent with the trades, information about insider trading would reach the markets immediately, having the proper effect on prices. Such an amendment of the applicable law has been endorsed by commentators. $^{38}$

\section{Flow of Information to the Markets}

Academic theorists have considered the effect of insider trading on the flow of information about the corporation to the markets. ${ }^{39}$ Since the incentive created by insider trading to release information to the markets is derivative, it is not surprising that the commentators' suggestions in this area differ enormously. Professor Scott, ${ }^{40}$ for example, distinguishes between good news and bad. According to Scott, managers have sufficient incentives to disclose good news without delay because they too will benefit from the price rise such a disclosure will cause. Indeed, their compensation is often tied to stock performance, as is the value of their human capital. Insider trading has the undesirable effect of encouraging them to delay the news in order to accumulate stock before the announcement. By contrast, management has a disincentive to air bad news. Only through insider trading and the information it would inject into the

${ }^{36}$ Trados too largo to bo oxocuted in the anonymity of the trading floor go through the more personal "block trading" specialists or "upstairs" brokers. In such cases, it is harder to maintain secrecy. Large-scale insider trading is thus likely to be discovered.

$\because 15$ U.S.C. $\$ 78 p$ (1988).

38 See genorally Gilson \& Kraakman, oupra note 21, at 632 (favorably considering preregistration of trades); Samuelsoni, The Trevention of Insider Ti uliny: A Proposul fur Revising Section 16 of the Securities Exchange Act of 1984, 25 HARv. J. LEGIS. 511 (1988) (proposing preregistration).

${ }^{39}$ V. Brudney \& M. Chirelstein, Corporate Finance, Cases and Materials 1024 (3d ed. 1987).

${ }^{40}$ Scott, Insider Trading: Rule 10b-5, Disclosure and Corporate Privacy, 9 J. LEGAL STUD. 801 (1980), excerpted in R. POSNER \& K. SCOTT, ECONOMiCS OF CORPORATION LAw and SeCurities REgulation 120 (1980). 
markets would this bleak information be released quickly. Otherwise, management would suppress it as long as possible in ordcr to prevent its negative effect on stock prices. ${ }^{41}$

Professor Clark $^{42}$ maintains that insider trading always delays the disclosure of information about the corporation to the markets, because insiders need time to trade on their knowledge. The prem ises of his argument are faulty, however. Major stocks are so liquid that institutional investors can move huge blocks virtually instantaneously without moving prices..$^{43}$ At the same time, insider trading accounts for only a "tiny fraction of one percent of the volume of trading." ${ }^{44}$ There is no doubt that insiders can trade instantaneously without moving priecs. Bccause the price changc will immediately follow the release of such information, and the insiders presumably want to bear the risks of investing in stocks as briefly as possible (in order to put their assets back into their favorite long-term investments), the insiders have an incentive to release the information immediately after they trade. ${ }^{45}$

Thus, both Clark and Scott may be wrong insofar as they claim that freedom to engage in insider trading might delay the release of information to the markets. Instead, it is submitted that insider trading accelerates the flow of information to the markets.

Compensation through options, by contrast, spurs management to release good news quiekly, but to sit on bad news. Indecd, a manager can never profit from airing bad news. She will not even be able to profit from the rebound of the price (after the fall) because options have a fixed strike price and can only be exercised onco. In fact, the manager could profit from this rebound only if the corpo-

${ }^{41}$ Scott, supra note 40 , also notes that a general disclosure rule might well be in the offing, citing the discussion of the grounds for liability in Financial Indus. Fund v. McDonnell Douglas Corp., 474 F.2d 514 (10th Cir. 1973). His prediction was correct, since Basic, Inc. v. Levinson, 485 U.S. 224 (1988), is a large step in that direction.

42 R. Clark, Corporate Law 268, $₫ 8.2 .3$ (1986).

43 Stern (moderator), A Discussion of Corporate Financial Information, 2 MidLaND CoRP. FIN. J. 40, 50-51 (Spring 1984) (discussion by McConnell) ("There may be some 300 firms that all institutional investors can talsc a position in, stocks which offer the liquidity to get in and out without moving prices around.").

${ }^{44}$ See supra note 33 . The small amount of insider trading volume also decreases the importance of all causation foundations for insider trading regulation, in particular Wang's argument that insider trading leaves the wrong amount of stock on the market.

${ }^{45}$ One could argue that insiders want to trade on more stock than they can manage by using only their own funds and the margin given by the brokerage houses. In such a case, the manager might want to obtain a "no questions asked" loan $\cdots$ a not perfectly legal loan. The manager will need time not for the trade itself, but for the loan arrangement. However, this scenario is not realistic. It is not a reason to conclude that insider trading will lead to market inefficiency. 
ration rushed to replace its options or to revise downward the strike price after the price drop and before the rise. But it is questionable whether such swift corporate action is likely.

In sum, the market efficiency logic does not provide a clear conclusion on the desirability of insider trading. First, the opportunity for secret insider trading available under the delayed disclosure mandated by current regulation negates any potentially useful effect from such trading's driving prices to their "right" level. Also, insider trading sometimes has the beneficial effect of inducing quicker disclosure, while compensation with options is inferior in this respect.

Agency Costs

The final stage in evaluating the desirability of insider trading is its effect on agency costs. ${ }^{46}$ Axiomatically, minimizing agency costs benefits shareholders and enhances firm efficiency. Commentators have suggested that insider trading minimizes agency costs by reducing management's salary, by aligning the risk preferences of management with those of shareholders, and by "signalling" competent managers. ${ }^{47} \mathrm{~A}$ comparison of the effects of insider trading with those of compensation packages including options ${ }^{48}$ or bonuses, however, shows that their effects are comparable to those forwarded by the advocates of unrestrained insider trading.

\section{Pay Reduction}

This argument, which assumes a very efficient market for managerial services, stipulates that if insider trading is allowed, competition will cause wages to decline by the amount of the expected trading profits - all to the shareholders' benefit. Although there is no evidence of such behavior, ${ }^{49}$ there is also no harm in analyzing the claim.

If managerial wages are reduced, the balance of management's compensation over salary comes from those shareholders' trades occurring before the events about which insiders trade. Sharehold-

${ }^{46}$ See R. POSNER \& K. SCOTT, supra note 40, at 39-40 (agency costs are the sum of principal's monitoring expenditures, agent's bonding expenditures, and the residual loss); Jensen \& Meckling, Theory of The Firm: Managerial Behavior, Agency Costs and Oumership Structure, 3 J. Fin. ECoN. 305 (1976).

${ }^{47}$ See Carlton \& Fischel, supra note 1, at 867 ("[B]etter managers will signal their quality by their willingness to tie a higher proportion of their compensation to stock performance.").

${ }^{4}$ Compensation packages using any of the various forms of options are substantively the same.

${ }^{49}$ Carlton \& Fischel, supra note 1 , at 859 . 
ers who do not trade reap the benefits of lower management compensation at the expense of trading shareholders.

Under this scheme, however, not all shareholders participate pro rata in management's pay. If fairness is equality of returns among shareholders, then this arrangement, by which shareholders who do not trade are advantaged, is unfair. Some shareholders finance management's pay by trading; the rest get a free ride. Easterbrook answers that the market may discount all shares for insider trading and that shareholders who lose in one transaction win the rest of the time due to the increased returns. ${ }^{50}$ But his response does not eliminate the inequality in returns; it merely asserts that the bets on stocks are fair. Shareholders who trade less frequently will still outperform the rest. ${ }^{51}$ But in addition to concluding that this result of insider trading is unfair, we should identify the frequent traders and the long-term passive investors. Members of the professional investment community trade more frequently than other investors..$^{52}$ Does the investment community need protection against inequality and oppression by individual investors, who are the less frequent traders? Some say that insider trading regulation benefits the professional investment community. ${ }^{53}$

Haddock and Macey ${ }^{54}$ and Carney ${ }^{55}$ explain that once insiders are forbidden to trade, market professionals, seeking such information by vocation, will take advantage of it rather than the shareholders, who have other full-time occupations. These authors argue that shareholders would rather allocate the profits of inside information to management in order to benefit the corporation, by means of a pay cut or as an extra incentive to management, than let the market professionals reap it.

In rebuttal, one should examine the interests represented by institutional investors. The investment community manages pension

${ }^{50}$ Easterbrook, supra note 35, at 325 (citing Scott, supra note 40, at 807-09).

${ }^{51}$ It is interesting to note that a similar problem arises when an issuer repurchases its stock; the sellers finance the price rise. Repurchases of stock by the issuing corporation are fundamentally similar to insider trading: an information-rich entity buys shares from information-poor dispersed shareholders. The legitimacy of repurchases by tender offer depends on proper disclosure. See SEC Rule 13e-4, 17 C.F.R. $\$ 240.13 e-4$ (1988), promulgated under section 13(e) of the Securities Exchange Act of 1934, 15 U.S.C. $\int 78 \mathrm{~m}(\mathrm{e})(1988)$.

${ }_{52}$ Stern, supra note 43 , at 45 (discussion by J. Stern) (2,200 traders account for $88 \%$ of the daily trading volume in the N.Y.S.E.).

${ }^{6}$ See infra text accompanying notes 54-56. See also Haddock \& Macey, supra note 23 , at $1458-59$.

s4 Haddock \& Macey, supra note 23, at 1478-79.

${ }^{55}$ Carney, supra note 14 , at 897. 
funds and other colloctively owned assets; the beneficiaries of those funds might prefer to take the chance that their fund will benefit by using information that cannot be used by the insiders. In such a setting, the beneficiaries would prefer that the market professionals obtain the information rather than have unproscribed insider trading, in which case the fund would simply participate pro rata in the increased value firms might have if the insiders' trading had the stipulated beneficial effects.

\section{Insider Trading Will Increase Management's Risk Propensity}

Managers are employed by only one corporation. They are also undiversified in their employment, obtaining the bulk of their income from the corporation. It may follow that they are more riskaverse than shareholders, who are the more widely diversified capital participants in the firm. ${ }^{56}$

Insider trading, according to this argument, increases management's tolerance for risk. When managers know that they can participate in the rise of share prices by accumulating shares while avoiding losses by unloading falling shares, they will have an incentive to embark on projects that provide insider trading opportunities. These are projects with outcomes that include an element of surprise-risky projects that are likely to cause fluctuation in the share prices. Yet management would not be expected to choose projects with low or negative expected values. Management can only profit from the price rises because section 16(c) of the 1934 Act forbids short selling to officers and directors. ${ }^{57}$ They will, therefore, prefer volatility only to a steady rise, not to a greater one. Still, a promising project with steady performance offers insiders more profit opportunities with less risk than an inferior volatile venture. Compensation with options and bonuses does not offer this opportunity to profit from volatility because, in order to do so, the corporation must constantly reissue or amend the options on very short notice whenever the share price bottoms out. Such swift and accurate corporate action is unlikely.

Along these lines, Jensen and Meckling in their seminal article ${ }^{58}$ see similarities between management's and creditors' attitudes toward risk: management wants the firm to remain healthy at all costs in order to protect salaries, just as bondholders hope for firm

${ }^{36}$ Soc Haddock \& Macey, oupra note 33 , at 1162 (citing Kraalkman, Corporate Liability Strategies and the Cost of Legal Controls, 93 YALE L.J. 857, 864 (1984)).

57 15 U.S.C. $\$ 78 \mathrm{p}$ (c) (1988) ("It shall be unlawful ... to sell ... if the person selling ... (1) does not own the security sold ....").

${ }_{58}$ Jensen \& Meckling, supra note 46. 
stability to protect the interest and principal of their bonds. Since neither group generally participates in the profits exceeding, respectively, their salary or interest payments, they wish the firm to avoid risks that might earn profits in which they would not participate. ${ }^{59}$

Clark takes the opposite position, claiming that management is already too risk-prone. ${ }^{60}$ The relationship between management and the shareholders is, in his view, like that between debtor and creditor. Only the debtor and owner of the residual enjoys a rise in the firm's value, while only the creditor is harmed by a drop. Just as owners of deeply indebted firms have an incentive to take excessive risks, so management, according to Clark, enjoys only the benefits of an increase in value, not the harm of a decrease. Professor Clark's view, however, is not shared in the related literature, where the prevailing view is that a decrease in the firm's value attributed to bad management diminishes the value of management's human capital. According to Clark, permitting insider trading will make management take even greater risks, to the detriment of shareholders. Thus, the basis of Clark's argument, that management is too risk-preferring, does not seem to be widely accepted.

Under the assumption that concern for the value of their human capital restrains management, Carlton and Fischel ${ }^{61}$ defend even short selling by insiders. ${ }^{62}$ They argue that short selling, unlike compensation through options and bonuses, enables managers to profit on the downside of their projects, thus increasing management's risk propensity even further. Under a short selling regime, however, management can profit from a project with a negative expected value. There is no reason to permit a perverse incentive and hope that the markets will take care of it, even if theory reassures us that they would. The markets must not only be efficient but look efficient, too. The appearance of impropriety increases the chances that investors' fear will drive them from the markets, causing a less liquid, less efficient market.

${ }^{59}$ Bondholders, who are owed a fixed amount, do not care about excessive profits even if such profits are obtained at the oxpence of only a slight incroase of risk to their principal. On the other hand, shareholders get nothing if the value of the firm oquals the amount owed to its ereditors and are hence indifferent between this value and zoro value. They have nothing to lose and everything to gain from a gamble to increase the firm's value.

${ }^{60} \mathrm{R}$. ClaRK, supra note 42 , at $267, \$ 8.2 .1$.

61 Carlton \& Fischel, supra note 1, at 858 .

${ }_{62}$ Short selling is prohibited by section 16(c) of the Securities Exchange Act, 15 U.S.C. $\int 78 p(c)(1988)$. 
Compensation packages (including bonuses and options) are only slightly different from insider trading in their effect on management's attitude towards risk. Apart from the comparisons already made above, there is concern that insider trading profits are poten. tially unlimited. Profits from options, on the other hand, are limited to the gains from the number of options held by the insider. Hence options induce even greater risk-taking than does insider trading. While insider trading can encourage management to pursue a "low risk.low gains" strategy in order to stake as much eapital as possible with little risk and still make a handsome profit, managers with a specific number of options must achieve substantial results for the corporation in order to produce substantial gains, and this they can do only by seeking high-return projects, which usually involve more risk.

\section{Insider Trading Will Signal Good Managers ${ }^{63}$}

The signalling argument is the least convincing argument that insider trading minimizes agency costs. If insider trading is part of management's compensation, then only the best managers, those confident they have the skill to affect the corporation's share price positively, will accept compensation with a lower base salary, expecting the remainder in insider trading profits. ${ }^{64}$ The confident managers will distinguish ("signal") themselves from the rest. This

${ }_{63}$ This discussion of agency costs omits the argument that when compensation includes insider trading, the firm pays more than the insider gets. Here again, insider trading operates exactly as options do.

This argument elaims that, as tho present price of a firm's stock anticipates its future prospects, the appreciation from good outeomes that the market has already anticipated will be minimal and will not provide insiders an opportunity for profits. On this view, insidore can profit only from unexpected good results. To those who adopt this hypothesis, insiders face an uphill strugglo to profit from insider trading and rational risk-aversc insidere chould prefor not to tio their compensation to the contingeney of achicving unexpected performance for the firm.

Under this argument; ineidere do not soe the compensation from insider trading the way a risk neutral person would. Consequently, the insiders should prefer positions with less total compensation but containing a larger fixed cash portion, thus wasting their value to society. See Easterbrook, Insider Trading as an Agency Problem, in J. PRATT \& R. Zeckhauser (eds.), Principals and AgenTs 87-89 (1985).

Compensation with stock options has the exact same result. So why have they survived and indeed prevailed? The answer should be that all the compensation packages contain options to induce officiency. Without this incentive, the value of the manager's work is so much lower (becaueo of increased agency costs, high risk of conflict of interests, and so on) that a position without such a compensation arrangement just cannot compete in payout with salarice including options. In such a casc, the above argument completely misses the target.

${ }^{\circ}$ Carlton \& Fischel, supra note 1, at 867. 
group, however, is not necessarily identical to the group of able managors. Confidence is hardly an exclusive companion of dexterity.

The signalling argument is also founded on the predictability of the firm's future performance, since "able" managers have to be capable of assessing the prospects of the firm under their helm in order to decide on accepting the contingent compensation through insider trading. A business cycle without surprises, however, is the exception rather than the rule. Firms operate in an unpredictable environment whose unpredictability varies with the risks of the industry in which each firm competes. In a highly unpredictable environment, the signalling argument is reversed: good managers who would command high salaries would not want to risk them on the firm's uncertain prospects. By contrast, less competent managers, unable to garner a high salary, would be more willing to take a chance for the higher pay they could not otherwise earn.

Compensation packages (including stock options and bonuses) result in exactly the same signalling effect. They are more attractive to good (or optimistic) managers than to bad (or pessimistic) ones. With regard to their effect on agency costs, the difference between insider trading and stock options is only marginal. They are equally effective as methods of compensation that promote efficiency and they have the same signalling effect. Only in the area of increasing the risk propensity of management do they differ, but in peculiar way: each has an advantage not enjoyed by the other. Insider trading allows management to profit from volatility more than options do, thus increasing management's tolerance for risk. On the other hand, options, which are limited in amount, do not allow for a low-risk strategy that would lead to small but sure gains which could be tapped through an immense insider trading scheme.

Arguments Based on Notions of Evolutionary Process

Proponents of insider trading find significance in the fact that such trading was never forbidden by contract; it has survived the test of time for a century. Easterbrook supports this position by suggesting a possible evolutionary process. ${ }^{65}$ Each incumbent management team would have an incentive to prohibit insider trading by young managers and be the only trading insiders in the company in order to maximize their own wealth. Since this has failed to happen for many management generations, we are left to infer that insider trading survived this evolutionary process on its merits.

Without challenging Easterbrook's empirical data, there are some objections to his reasoning. First of all, it would show questionable

${ }^{65}$ Easterbrook, supra note 63, at 90. 
ethics if incumbent management engaged in a practice that it prohibited for subordinates. Management also would not want to call attention to the issue by even negotiating with junior management to prohibit insider trading. Publicity of such negotiations could only harm the inside traders by reopening a settled issue. In addition, if insider trading hurt stockholders and not fellow traders, there would be no reason why incumbent management would not want to share this benefit with the other management ranks. Easterbrook maintains that if insider trading is inefficient, then incumbent management will not allow novices to practice it. This prohibition will increase the firm's return, thereby increasing management's income (and the value of management's human capital). The boon in such a case would be negligible. ${ }^{66}$

Easterbrook also argues that if insider trading were indeed inefficient for the firm, it would not have survived the test of time. The first firm to ban the practice would gain an advantage over its competitors. Its stock would command higher prices, thereby lowering the cost of raising capital in the markets and forcing other firms in the industry to follow suit. Every upstart firm has a strong incentive to adopt measures giving it an advantage over its competitors, and competitive markets therefore would adopt such measures. Yet firms did not prohibit their insiders' trading. Consequently, one is left to infer, insider trading is not an inefficient compensation device. ${ }^{67}$ But, indeed, insider trading is not inefficient. It closely compares with options as a compensation device that promotes efficiency. The test of time has to be limited: it proved that a prohibition of insider trading by a specific firm does not increase efficiency, in the specific firm or in the market. ${ }^{68}$ This is very different from concluding that the absence of a prohibition proves that insider trading is efficient. Insider trading can be irrelevant to the firm's returns (as distinguished from its effect on the market), or, if relevant and undesirable, its proscription by the individual firms could be too expensive.

${ }^{68}$ It depends on the important assumptions that harm to the firm from insider trading will: (1) reduce insider trading profits of senior management, and (2) thereby cause the value of the human capital of senior management to drop (even though this value would not drop from the harm caused by senior sending itself). Both propositions are dubious at best.

${ }^{67}$ Easterbrook, supra note 63 , at 90-91.

${ }^{68}$ Easterbrook points out that the difficulty of policing similarly makes the prohibition of insider trading by individual firms inefficient. This problem suggests that insider trading could be introduced only by a general legal rule, not by an individual firm's charter or by-laws. See infra text accompanying notes 69-71. 
There is one more obstacle in the way of a corporation wishing to reach an agreement with its managers on insider trading. Insider trading probably is not very costly for the firm if the firm is envisioned, as it was traditionally, as an entity separate from its shareholders. Insider trading does not put a direct financial drain on the firm and even has beneficial side effects for the corporation. This means that the ability to trade on inside information has a greater value for insiders than the costs imposed on the firm. The field is thus tilted against reaching an agreement limiting insider trading because in order to persuade insiders to forego trading, the firm would have to pay more than the benefit it would receive from the prohibition.

Easterbrook also mentions the impossibility of enforcement as another argument why the prohibition of insider trading by the firm is not feasible. ${ }^{69}$ Since firms cannot police insider trading, ${ }^{70}$ why should they proscribe it? Easterbrook reasons that dishonest managers who intend to trade will be attracted to the firm because the firm will be paying higher wages to keep its honest managers. The firm will then find out that it is overcompensating its management by giving it high wages in addition to insider trading, and will reduce salaries, losing the honest managers who would now be underpaid.

Easterbrook also explains that the difficulty of detecting breaches will dilute any gains from the prohibition:

[T] he difficulty of detecting who does and who does not comply with a prohibition on inside trading also makes it very hard for a firm to capture the gains of a prohibition, even if the prohibition is both socially beneficial and perfectly enforced. Suppose firm A adopts and enforces a prohibition. It communicates the news to the market, and the price of its stock rises, reflecting the value of the new measures. Now firm B copies the announcement but not the enforcement policy. The market will be uncertain whether firm $B$ in fact has abolished trading by its insiders. The price of $B$ 's stock will reflect the benefits, discounted by the probability of enforcement. The more firm B looks like firm A to the market, the higher its price. Many B-type firms will try to take a free ride on the efforts of A-type firms. The strategy is more profitable to $B$ than to $A$, because only $A$ incurs enforcement costs. The more successful B-type firms are in mimicking the appearance but not

${ }^{69}$ Easterbrook, supra note 63, at 94.

${ }^{70}$ Firms never know when management is trading on inside information (nor even that it is trading) and they do not want to ban all stock ownership by management (which would make enforcement very easy) because such ownership is beneficial to everybody. 
the reality of prohibition, the lower the price of A-type stock, because the market cannot trust A's representations. And if, because of the mimicry, the A-type firms cannot capture the full benefits of their enforced prohibition of trading, they too will find it most profitable to adopt strategy $\mathrm{B}^{71}$

Since the pretense of a proscription of insider trading is more profitable than the enforced prohibition, firms that proscribe insider trading lose the incentives to enforce this policy. They will have larger benefits by its unenforced proscription. This further suggests that individual firms do not have the incentive to protect the interests of the trading public, particularly when the interests of those firms are well separated from those of the public. Investor protection must lie elsewhere, with a government agency like the SEC, or with the courts.

The Problem of the Implicit Nature of Insider Trading as Compensation

From a legal perspective, the differences mentioned above are less important that the fact that compensation through stock options is explicitly contracted for, while insider trading is never endorsed by the firm. If insider trading is a form of management compensation, then it should be allowed explicitly. Implied compensation for fiduciaries is not permitted under state agency law. ${ }^{72}$ Two factors help determine whether insider trading should be considered compensation: (1) the absence of any specific agreement in employment contracts, and (2) whether insider trading usurps corporate information.

The lengthy and persistent absence of any express agreement on insider trading in employment contracts requires attention. The silence should be interpreted. One may begin by seeking to determine the default beneficiary of the trading rights on inside information. For assistance, we should examine the nature of a hypothetical employment contract prohibiting management from trading on inside information. Indecd, a clause prohibiting manage ment from trading seems to be a contractual detriment to manage ment, warranting additional consideration from the employer firm. Thus, the absence of such a clause can only be interpreted as a prohibition if insider trading were in the control of the firm. The

${ }^{71}$ Easterbrook, supra note 63, at 94-95.

${ }^{72}$ See R. Clark, supra note 42 , at 280, 8.3.1. See also Restatement (SeCOND) of AGENCY $\ 388$ comment $\mathrm{c}(1958)$ (prohibiting profit from use of information even without harm to principal). 
firm would have to allow management to engage in it by a clause that would have value to management. But it seems that insider trading was a eommon practice in the stock exchanges; hence, such a clause would have little value for management..$^{73}$ It is not a term handed by the firms to management in the sense discussed above. Historically, insider trading was perceived to affect only shareholders, as distinct from their corporations. As a result, it was not prohibited by default in a silent employment contract. Since management was not restrained from it, insider trading cannot be considered compensation handed to management silently by the firms.

It must be stressed that the issue is how to distinguish between a legitimate and a fraudulent variation of the same practice. Until recently, common law fraud rules were considered sufficient. Insider trading has become the target of strieter regulation only sinec the $1960 \mathrm{~s}$, when, coincidentally, the prospect of computerized monitoring of market transactions dramatically reduced the costs of detecting and enforcing the prohibition.

If a form of insider trading is legitimate in the eyes of the law, and management receives its benefits as the default beneficiary, then insider trading cannot be a compensation arrangement because the law already permits it. However, some forms of insider trading are unquestionably fraudulent. A firm's permission for employees to commit fraud is hardly a compensation device, since the decision making that leads to a permission to trade on inside information is skewed. The firms will permit a practice from which they are only indirectly injured, the direct victims being the shareholders and market participants. Consequently, these are "aggravated" kinds of insider trading that do not withstand criticism by disguising them as forms of compensation. Once again, the problem reduces to one of where the line between legal and illegal insider trading will be drawn.

\footnotetext{
${ }^{73}$ However, a prohibition of insider trading derived from agency law is possible. See Restatement (SeCOND) of AGEnCy $\$ 388$ comment $\mathrm{e}$ (1958) (prohibiting profit from u3e of information even without harm to principal); Is insider trading illegal under this rulc, with no noed for epocial fraud rulcs? Maybe not: Corporate officers conceivably could invoke the business judgment rule were the allocation of such information ehallenged. The discussion thue conters on the notion of "rights in information" as a ground for the proscription of insider trading, even though; as we saw, insider trading normally tends to be considerod fraudulent. Beyond proving the infinite complexity and interdependency of the world, it is worth remembering that this point comes up only in the discussion of insider trading as a compensation device. The vagueness and breadth of the notion of fraud gives a more complete explanation of the insider trading rulcs.
} 
Whether insider trading usurps corporate information, in violation of agency law, ${ }^{74}$ brings us once more to the most crucial issue in the insider trading debate, the nature of this information. Categorizing forms of information, one of the most evanescent intangibles, is obviously difficult. The related literature often refers to "soft" and "hard" information, but the definitions are far from clear. Hard information includes all information about the past, all historical information. Soft information comprises all uncertainties and expectations for the future. However, there is an intermediate area of information about the immediate future that can reach a higher degree of certainty than the more remote soft information. When is information sufficiently certain so that acting on it is equivalent to profiting from it (because of the extremely low risk involved)? It appears that this is the point where a distinction should be drawn between usurping corporate information and trading on educated estimates of the future. Trading on "knowledge" should be considered compensation, while trading on estimates should not only be considered the right of insiders, but should even be encouraged because of its incentive effects. Notice that trading on "knowledge" provides weaker incentives, because the relevant event is expected anyway. By contrast, if managers' actions can affect the fulfillment of these expectations, the managers' trading on these expectations should enhance their efforts.

\section{Cross INSIDER Trading}

\section{The Legal Analysis}

In cross insider trading, the holder of the informational advantage trades in stock other than that of the corporation with which he has a fiduciary relationship. An alien corporation is the object of the crosstrader's inside information, while the crosstrader's own corporation is the source. The distinction between cross and classical insider trading can now be made because insider trading has been confined to the classical variation.

The interpretation of Rule $10 \mathrm{~b}-\mathbf{5}$ as a prohibition against insider trading started with In re Cady, Roberts and SEC v. Texas Gulf Sulphur. ${ }^{75}$ These cases found a fraud violating Rule $10 \mathrm{~b}-5$ if a possessor of "material nonpublic" information did not disclose the

${ }^{74} \mathrm{R}$. Clark, supra note 42 , at 280 (referring to Restatement (SeCond) of AgenCy 388 comment $\mathrm{c}(1958)$ (prohibiting profit from use of information even without harm to principal)).

${ }_{75}$ SEC v. Texas Gulf Sulphur Co., 401 F.2d 833 (2d Cir. 1968); In re Cady, Roberts \& Co., 40 S.E.C. 907 (1961). See supra notes $9-11$ and accompanying text. 
information before trading (the "disclose or abstain" rule). The definition of insider trading did not develop strong reliance on the existence of a fiduciary relationship until Chiarella $v$. United States. ${ }^{76}$ In that case a fiduciary's breach of the duty to disclose was held to be a prerequisite for a Rule $10 \mathrm{~b}-5$ violation. This explicit requirement of a fiduciary link between the insider and the other side of the trade is a major pivotal point in the interpretation of Rule 10b5. There were two immediate reactions: (1) The SEC promulgated Rule 14e-3, which eliminated the "fiduciary breach" requirement in all tender offer-related cases of insider trading; ${ }^{77}$ and (2) the Second Circuit adopted the misappropriation theory in United States $v$. Newman, ${ }^{78}$ an interpretation of $10 \mathrm{~b}-5$ aspiring to award liability regardless of a fiduciary duty. Under this theory, there is a $10 \mathrm{~b}-5$ fraud if improperly obtained material nonpublic information is used for trading. ${ }^{79}$ The "in connection with a purchase or sale of securities" requirement of Rule $10 \mathrm{~b}-5$ is satisfied because the misappropriator trades. The person with whom the insider trades is irrelevant; fraud consists in taking (misappropriating) the information.

The Second Circuit, however, denied a private right of action based on the same facts in Moss $v$. Morgan Stanley. ${ }^{80}$ But a recent amendment to the Securities Exchange Act overrules Moss. The Insider Trading and Securities Fraud Enforcement Act of 1988 permits private rights of action for contemporaneous traders in all insider trading cases. ${ }^{81}$ While this legislative development overrules Moss, it does not directly interfere with the interpretation of Rule 10b-5, neither endorsing nor rejecting the misappropriation theory. The Carpenter ${ }^{82}$ decision split the Supreme Court on the application of the misappropriation theory to rule $10 \mathrm{~b}-5$ cases, frustrating those who were looking to the Court for guidance. The Court may have split over one or more of three possible problems. There could have been difficulties with the merits of the misappropriation theory itself. There could have been problems with its application to the

${ }^{76} 445$ U.S. 222 (1980). See supra note 12 and accompanying text.

717 C.F.R. $\ 240.14 \mathrm{e}-3$ (1988). See supra note 9 and accompanying text.

${ }^{78} 664$ F.2d 12 (2d Cir. 1981), aff'd on remand, 722 F.2d 729 (2d Cir. 1983).

${ }^{79}$ See Aldave, supra note 2 , at 114 .

so 553 F. Supp. 1347 (S.D.N.Y.), aff'd, 719 F.2d 5 (2d Cir. 1983).

${ }^{81}$ Section $20 \mathrm{~A}(\mathrm{a})(1)$ of the Securities Exchange Act of 1934, as amended, 15 U.S.C.A. $\$ 78 \mathrm{t}-1$ (a) (West Pocket Part 1989).

${ }_{82}$ Carpenter v. United States, 484 U.S. 19 (1987). See supra note 6 and accompanying text. See also Crespi, The Availability After Carpenter of Private Rights of Action Under Rulo 10b.5 Based Lpon tho Misappropriation of Information Concerning Acruisitions. 26 Aм. Bus. L.J. 709 (1989); Beck-Dudley \& Stephens, The Efficient Market Theory and Iivider Trading: Are We Headed in the Right Direotion?, 27 AM. Bus. L.J. 441 (1989). 
facts in this case, because Winans, the defendant, produced the exploitable information himself. It is unclear whether a "physical" taking is required. Alternatively, the problem may have been whether the misappropriation theory should apply when the defrauded entity, the Wall Street Journal, is not a market participant in any way, thus implying a failure to satisfy the $10 \mathrm{~b}-5$ requirement of a fraud "in connection with the purchase or sale of any security."

The decision itself is not very helpful in this respect. After reciting the decisions of the courts below, the Court dispensed with the securities laws with a single sentence: "The Court is evenly divided with respect to the convictions under the securities laws and for that reason affirms the judgment below on those counts." 83 The Court was careful not to commit itself. One way to discover the reasoning underlying this statement is to proceed by elimination.

The first possibility is that the Court split over the merits of the misappropriation theory. Carpenter, however, was an innovative and courageous decision with respect to mail and wire fraud interpretation, as commentators have suggested ${ }^{84} \mathrm{~A}$ few months before Carpenter the Court decided McNally v. United States, ${ }^{85}$ where mail and wire fraud was held to be "limited in scope to the protection of property rights." 86 However, in Carpenter this limitation was interpreted to include intangible property rights. Commentators have argued that Carpenter weakens the McNally limitation, because a change in the pleadings would be sufficient to satisfy the new mail and wire fraud interpretation. Intangible rights will merely be expressed as intangible property rights, which is quite plausible if they are exclusive and economically exploitable. ${ }^{87}$ If the Court took such an aggressive course in the interpretation of the mail and wire fraud statutes, would it not seem strange to conclude that the Justices shied away from the misappropriation theory? The view that the Supreme Court does not disapprove of the misappropriation theory also might be slightly encouraged by the denial of certiorari in United States $v$. Newman. ${ }^{88}$

484 U.S. at 24.

${ }^{84}$ See Bagby, supra note 2, at 206. See generally Note, The Mail and Wire Fraud Statute's Protection of Property Extends to Intangibles Such as Confidential Business Information: Carpenter v. United States, 19 TEX. TECH. L. REv. 1539 (1988).

${ }_{85} 483$ U.S. 350 (1987).

${ }^{8}$ Id. at 360 .

${ }^{87}$ See generally Note, supra note 84 , at 1554; Coffee, The Criminal Law Status of Confidential Business Information 15-19 (unpublished draft, Oct. 4, 1988) Cf. Bagby, supra note 2 , at 205 n.7.

s8 664 F.2d 12 (2d Cir. 1981), aff'd on remand, 722 F.2d 729 (2d Cir.), cert. denied, 464 U.S. 863 (1983). 
One might suppose that the Court split over application of this rule to Winans because he personally produced the information he "misappropriated." However, this possibility must also be rejected because the same objection was dismissed in relation to the mail and wire fraud counts. The defendant also used the Journal's schedule of publication for the timing of his trades. This schedule was not his creation, but the Journal's. ${ }^{89}$

The element surviving elimination is that the Court split over whether the misappropriation theory should apply in a case where the "misappropriatee" did not trade in the market. Commentators $\mathrm{s}^{90}$ have pointed to the fact that since the defrauded entity, the Wall Street Journal, was not a participant in the marketplace, no fraud was committed "in connection with the purchase or sale of any security." 91 This thorny unresolved issue puts into question the applicability of Rule $10 \mathrm{~b}-5$ in this case. Consequently, this last alternative is the most likely reason for the Court's reluctance to take a position in Carpenter.

The misappropriation theory posits that a Rule $10 \mathrm{~b}-5$ fraud is perpetrated by the misappropriation of the information and the subsequent use of it for profit. The purpose of the introduction of the misappropriation theory was to avoid the Chiarella paradox, which allows the use of inside information in trading in stock of "strangers," corporations to whose shareholders the trader does not owe a duty to disclose. The Chiarella paradox is founded on the notion that there is a Rule $10 \mathrm{~b}-5$ fraud only where the insider owes the victim a fiduciary duty to disclose. However, the misappropriation theory did not cure the Chiarella paradox. The paradox arose again because the Court searched for a trading victim of the misappropriation in order to find fraud in connection with the purchase or sale of a security, as Rule $10 \mathrm{~b}-5$ requires.

By contrast, the fraud-on-the-market theory used in the merger negotiations disclosure context does not require a close connection between the perpetrator and the victim. On the contrary, the fraudon-the-market theory serves the purpose of partially overcoming the connection requirement by easing the reliance standard. Fraud-

${ }^{29}$ See Carpenter 484 U.S. at 25-26 (contents and timing of the column are property rights of the Journal).

${ }^{90}$ Note, supra note 84 , at 1551 ("'SS]ome scholars feel that the fraud ... was not sufficiently in connection with the purchase or sale of any security ...."').

91 17 C.F.R. $\ 240.10 \mathrm{~b}-5$ (1988). Although it accepted such "connection with purchase or sale," the Second Circuit noted that it was "very tenuous indeed." United States v. Newman, 664 F.2d 12, 18 (2d Cir. 1981). Cf. $i d$. at 20 (Dumbauld, J., dissenting) (dissenting on the "connection" point, but concurring in the mail and wire fraud conviction). 
on-the-market may assist in overcoming the Chiarella paradox. Reliance by investors may exist without a fiduciary duty owed to them by an alien corporation's management. However, it does not create a duty to disclose on the latter's part. The fraud-on-the-market theory provides that trading at wrong prices is equivalent to being defrauded. It reinforces the view that accuracy in securities prices is a goal of Rule $10 \mathrm{~b}-5 .{ }^{92}$ Once this crucial connection is accepted, any behavior causing inaccurate securities prices can be characterized as a 10b-5 fraud. Of course, a fiduciary duty was still present in Basic, running from the nondisclosing management to the investors. Essentially, the misappropriation theory is unnecessary; it was held, indirectly, to have nothing to add. ${ }^{93}$

Therefore, the choices confronted in a cross insider trading case are similar to those present in Carpenter. First, the misappropriation theory may require that the object of the misappropriation be a market participant. This, however, would still permit cross insider trading while retaining unity of interpretation with Chiarella. Second, market participation by the misappropriation victim could be ignored, thereby banning cross insider trading. This, however, would force Rule $10 \mathrm{~b}-5$ into the threshold of state law, and would replace the "disclose or abstain" rule by a more complex but substantially identical theory. ${ }^{94}$ Finally, Chiarella could be overruled and the "disclose or abstain" theory could be accepted without the requirement of a fiduciary link, thereby accepting "the market" as the

${ }^{92}$ Basic, Inc. v. Levinson, 485 U.S. 224, 241-42 ("'The fraud on the market theory is based on the hypothesis that ... the price of a company's stock is determined by the available material information.... Misleading statements will therefore defraud purchasers of stock ...."').

${ }_{93}$ All other things being equal, the misappropriation theory is inferior to the previous interpretations of Rule $10 \mathrm{~b}-5$. The misappropriation theory is logically more remote, assigning liability for the taking of information instead of having a notion of "fraudulent trading." It almost duplicates the rule that fiduciaries should not profit from their employer's information, a rule that is entirely contained in state agency law. The Supreme Court has objected to the development of $10 \mathrm{~b}-5$ interpretation into the area of state law in Santa Fe Indus., Inc. v. Green, 430 U.S. 462, 474 n.14 (1977). See generally Brooks, Rule 10b-5 in the Balance: An Analysis of The Supreme Court's Policy Perspective, 32 HASTINGS L.J. 403 (1980); Ferrara \& Steinberg, The Interplay Between State Corporate and Federal Securities Law, 7 DEL. J. CoRP. L. 1, 5 (1982); Ferrara \& Steinberg, Reappraisal of Santa Fe: Rule 10b-5 and The New Federalism, 129 U. PA. L. REv. 263, 266 (1980); Gorman, At The Intersection of Supreme Avenue and Circuit Street: The Focus of Section 1O(b) and Santa Fe's Footnote 14, 7 J. CoRP. L. 199, 200-06, 224-25 (1982); Stricklin Krendl, The Progeny of Santa Fe v. Green: An Analysis of the Elements of a Fiduciary Duty Claim Under Rule 10b-5 and a Case for Federal Corporation Law, 59 N.C. L. REv. 231, 231, 315-21 (1981).

See supra note 93. 
object of the fraud. This would unify the interpretation of Rule 10b5 for both insider trading and merger negotiations disclosure purposes. If cross insider trading is undesirable, the Court should overrule Chiarella and reinstate the "disclose or abstain" theory, while relaxing the restraint of requiring a narrow fiduciary duty in order to mandate disclosure. Alternatively, if overruling Chiarella is impossible, it could be best for the Court to relax the market participation requirement before applying the misappropriation theory.

The Proposed Vehicle to a Cross Insider Trading Proscription: Fraud on the Market

Recall that shareholder injury from classical insider trading ${ }^{95}$ founded on fraud-on-the-market causation is slightly broader than the form accepted in Basic. ${ }^{96}$ Shareholders were injured because they traded at a fraudulent price, while the trading insiders breached their duty to disclose nonpublic information to fellow shareholders. However, in cross insider trading the existence of a similar duty is not so clear. In classical insider trading there is a judicially accepted duty to disclose the information on which the insider is trading. This duty is founded on the fiduciary relationship between management and shareholders. In cross insider trading this duty is not established. By contrast, Chiarella implies that lack of a fiduciary link with the insider's counterparty absolves the insider of a duty to disclose. Establishing such a duty to disclose is the hurdle towards a proscription of cross insider trading.

If there is a duty to disclose in cross insider trading similar to the duty in classical insider trading, then the injury analysis is identical. Trading shareholders are injured because their transactions occur at the wrong prices due to the nondisclosure of insider information by the cross traders.

The insiders' obligation to disclose is absent if there is no fiduciary relationship. Although this is true in the context of a fiduciary duty based on corporate law, Rule $10 \mathrm{~b}-5$ should be interpreted consistently with its purpose of protecting the integrity of the markets. Insider trading fraud, based on Rule 10b-5, should not be limited to intracorporate fraud. The duty to disclose should be based on a duty to the market participants. Precedent for this duty is found in the foundations of the fraud-on-the-market theory, the Basic case and its progeny. Once this duty is established, Rule $10 \mathrm{~b}-5$ applies

${ }_{95}$ See supra text accompanying notes 15-32.

${ }_{96}$ See supra note 18. 
without further complications and without the fiduciary relationship limitation imposed by Chiarella. The following exposition of the cross insider trading policy supports this recommendation.

\section{The Policy Debate}

There is no well developed policy debate regarding cross insider trading. ${ }^{97}$ The similarities between classical and cross insider trading create the false impression that the same policy considerations apply in each case. Classical insider trading is addressed as a conflict between insiders and shareholders. By contrast, cross insider trading places insiders opposite the market in general. Only a few arguments apply to both forms of insider trading. These are the arguments that focus on the effect insider trading has on the markets. These include the arguments that address the traders' injuries based on nondisclosure, ${ }^{98} \mathrm{Wang}$ 's argument that price movements are unevenly distributed in favor of insiders, and the debate on how insider trading affects stock pricing.

The other arguments related to the insider trading debate are out of place in a debate on cross trading. The flow-of-informationto-the-markets argument, the entire agency cost discussion, and the management compensation issue are not applicable to cross insider trading, either because these arguments assume that the insiders are managers of the corporation in whose stock they trade or because they focus on the insider/managers' relationship with shareholders.

A distinctive feature of cross insider trading is that it raises more serious conflicts of interest than classical insider trading, both in the takeover context and in everyday corporate life. It is useful to examine the nature of the conflict of interest posed by cross insider trading in both contexts.

\section{Conflict of Interests in Takeovers}

Apart from the obvious injury cross insider trading inflicts on acquirers by raising the target's price, ${ }^{99}$ cross insider trading mis-

\footnotetext{
${ }^{97}$ The trading on inside information not included under the Chiarella limitation does not even have an accepted name. Some refer to it as outsider trading, which leaves outsiders who have no information advantage with no name. See supra note 2. See also Aldave, supra note 2, at 112; Bagby, supra note 2.

${ }_{98}$ The sole difference in the analytical process is the lack of a Chiarella-type fiduciary duty to disclose. This article advocates overruling this limitation. The "fraud on the market" notion suggests that the market needs protection regardless of the relationship between the perpetrator of the fraud and the market participants. See supra text accompanying notes 95-97.

${ }^{9}$ Insider trading will increase demand for the target stock and thereby raise its
} 
aligns the interests of insiders and shareholders to such an extent that it creates conflicts of interest. If insiders are allowed to trade, they may pursue trading profits instead of a sensible corporate policy. When deciding on corporate policy, managers who can profit by trading in the stock of the acquired firm may view takeovers as more lucrative, because they provide an extra and secret bonus for management. Under such pressures, insiders may engage in more takeovers than they might have otherwise. Theory suggests managers will engage in takeovers until the return from them is not obviously negative for their firm. ${ }^{100}$

However, this point will not be the optimum for the acquirer's shareholders or for the economy. Shareholders want only those takeovers that make sense economically, and that are profitable for the firm, not only for its insiders. The economy needs only those takeovers that create value, not takeovers that just reshuffle corporate assets.

This adverse effect is generated by cross-trading, and not by classical insider trading. Because in classical insider trading insiders are trading only in the stock of their own corporation, their interests do not deviate greatly from the interests of most other shareholders. The major result of this is an increase in management's risk propensity. Although it is unlikely that management would pursue actions that negatively impact share value, insider trading would permit management to profit on volatility. If insiders' "short" selling is prohibited by section 16 (c) of the 1934 Act, there are no instances, other than cross trading, in which insiders can profit from a project that does not also have a positive expected value for the shareholders.

\section{Conflict of Interests In Situations Not Associated With Takeovers}

While takeovers have been and may be expected to remain a central object of regulation and debate, the previous analysis on the effects of cross-insider trading on takeovers may be moot. Rule $14 \mathrm{e}-3$ prohibits all trading on nonpublic information concerning pend-

price. This happens either directly or indirectly through its informational effect, if the effect of demand alone is considered insufficient. If the price rise of the target causes the acquirer to increase its bid higher than it would have absent such trading, then insider trading increases the acquirer's total takeover expenses.

${ }^{100}$ At that point, the value of the insiders' human capital will begin to be put in jeopardy, suggesting that they will stop there. Nothing guarantees this, but the assumption of rational decision making by management suggests it. The risk of management's turning irrational under strange external pressures, such as an imminent personal bankruptcy, is disccurtad in the prica of stock Søe, e.g., Carlton \& Fischel, supra note 1 , at 872 . 
ing tender offers. There is no analogous rule, however, concerning other corporate transactions that have a similar potential to move stock prices.

To illustrate, consider a big corporation with a stable and established business, a fictional McDonnell Douglas. At a certain point this corporation decides to subcontract some of its business. Several small corporations compete for these contracts, which are huge by their standards. The stock market discounts the probability of getting the pending contract for each and prices the stock accordingly. The corporations that do not trade publicly do not receive such attention. These contestants fall into three categories: (1) the corporations that the market considers likely to get the contract, (2) those that are considered unlikely to get the contract, and (3) the private corporations that are not traded. Corporations in the first category will increase in value only modestly if they actually get the contract. The contract award is not a surprise, so the market will already have priced them for this expectation. Corporations in the second category will experience a substantial price rise, because they were a long shot with lower odds of winning the contract. If management of the prime contractor is allowed to trade in suppliers' stock, then it will have an incentive to review only candidates in the second category due to the opportunity they offer for a substantial appreciation. At the other end, unlisted candidates will be reviewed only if required to do so. This form of trading creates an obvious distortion in decision making, and the traders' profits are not shared with the traders' corporations.

Classical insider trading results in no such distortion of management's decision making in similar cases. If the managers of the fictional McDonnell Douglas trade in their own corporation's stock, their incentive will be to pick the subcontractor that will benefit their corporation. They are indifferent about the effect that the contract award has on these other companies.

Counter-Arguments to Cross Insider Trading

\section{A Prohibition of Cross-Trading Did Not Emerge on the Markets}

Neither investors nor corporations have tried to ban cross insider trading. Presumably, this argument, which has been used by Easterbrook to criticize the regulation of classical insider trading, ${ }^{101}$ could be used as well against a proposal to prohibit cross-trading. Companies that present cross-trading opportunities are the firms 
that can affect the future of other companies, usually only very large corporations.

The evolutionary process, however, can hardly work in these circumstances. The evolutionary process would impose a clause prohibiting cross-trading by making the market realize that new issues of stock are more attractive if the issuer prohibits crosstrading. However, young upstart firms do not face the problems that cross-trading generates. The prospect of becoming big and having a big impact on other firms is uncertain and lies a number of years down the road. Not even the investors have such a longterm perspective as to change their valuation for the "new issue" if it includes a prohibition of cross insider trading. Not only will the prohibition apply after several years, but the proportional value of such a clause is minimal in view of the gigantic appreciation due to the growth of the upstart into a major corporation. Because it does not appear that there is any competitive advantage in developing such a clause prohibiting cross-trading, little importance should be assigned to the fact that it has not developed.

Should All Other Stock Ownership of Management Be Forbidden?

One would assume that, if cross insider trading is bad, a rule prohibiting all stock ownership by management would be beneficial. The argument could be made that management would rather influence the price of a stock it owns than that of a "stranger." Although this sounds correct, it does not correspond to reality. The scheme of having insiders who own stock in the suppliers or the subcontractors of their own corporation is different from cross-trading. Insiders might exercise less control over the subcontractors because if they fire the subcontractors their stock holdings will depreciate. However, it is crucial to avoid distortions in corporate decision making, and the original award of the contract is the most important decision point. Thereafter, management can always sell its holdings before a subcontractor is fired. Unless management members are pursuing an active investment strategy in their personal finances, it is unusual for them to own large amounts of stock in a corporation that might be a candidate for such a contract. Normally they will be following a personal investment strategy of diversification. It can safely be assumed that the chance of a minuscule additional return will not drive management away from sound decision making practices. By contrast, if managers are allowed to trade in the subcontractor's stock, their returns could rise substantially.

\section{Cross-Trading Is Not Embraced by Self-Dealing}

The example of managers, who already own substantial amounts of the target of the preferential treatment, is different. Here, there 
is not unfair trading, but there is the potential for unfair decision making. This situation should be addressed along with self dealing: Allegations of self-dealing, however, cannot be triggered by crosstrading because of the difference in the order of events. In crosstrading thoro is no prior stock ownership in the corporation that receives preferential treatment by the insiders.

In a typical cross trading transaction, the decision for the corpo ration to subcontract comes first. Thereafter, management determines the beneficiary corporation. At this point self-dealing could arise if management had a substantial ownership interest in the corporation selected. In cross-trading, however, management's decision making is influenced at a time when there is no ownership in the recipient of this preferential treatment. Only after the decision will management profit through the stock purchase and the announcement of the recipient. In this ordering of events, selfdealing does not apply.

\section{CONCLUSION}

Cross-trading, or insider trading across corporations, is more undesirable than classical insider trading. Although no regulatory action is directly suggested here, a change in the law to proscribe cross insider trading would be beneficial. This article suggests that the adoption by Basic of the fraud-on-the-market theory to establish the element of reliance in a Rule $10 \mathrm{~b}-5$ case affirms that the goal of Rule $10 \mathrm{~b}-5$ is accurate securities prices. Attainment of this goal will be furthered by proscribing cross insider trading. This could be accomplished by imposing a wider duty to disclose that is not based exclusively on a traditional fiduciary relationship. A regulation to the effect that section $10(\mathrm{~b})$ and Rule $10 \mathrm{~b}-5$ are violated regardless of a fiduciary duty link between the trader and the victim would have this result. However, one should not expect such a development, in view of the tendency to leave the interpretation of Rule $10 \mathrm{~b}-5$ to the courts. It is best left to the initiative of the same courts that read the fiduciary duty requirement into Rule $10 \mathrm{~b}$ 5 to now extract it, a position consistent with the Blackmun-Marshall dissent in Chiarella. ${ }^{102}$

This article has dealt with both classical and cross insider trading. Numerous arguments have been presented and evaluated. First, using the fraud-on-the-market theory, this article introduced an analysis of shareholder injury attributed to insider trading. Nondisclosure by insiders of their information causes investors to trade 
at incorrect prices to their detriment. The argument that insider trading redistributes price moves in favor of insiders was found valid, but was found to be only a minor problem.

Insider trading arguably can increase capital market efficiency. But the only way insider trading benoficially moves priecs is through revelation of the insiders' estimates of share values. Secret insider trading leaves prices unaffected. This supports commentators' suggestions for speedier filing of insiders' trades. Freedom to engage in insider trading, however, can provide an incentive for management to release carlier news about the corporation.

Although a case can be made that freedom to engage in insider trading could reduce agency costs, this reduction is finaneed entirely by the shareholders who trade frequently. An insider trading prohibition does not necessarily benefit shareholders because, after management, the group most likely to take advantage of the inside information is market professionals. Insider trading has the beneficial effect of aligning management's risk propensity with that of the investors. Insider trading decreases agency costs only through a signalling process primarily for firms that operate in safe environments, a rarity in the real world. In addition, any signalling effect of insider trading could be duplicated by means such as compensation through options and bonuses.

In contrast to classical insider trading, cross insider trading has been found unquestionably undesirable. Cross-trading produces acute conflicts of interest where it induces management to actions that might be adverse to the corporation's performance. Due to this conflict, the requirement of a fiduciary relationship in Rule 10b-5 fraud cases should be eliminated. Fortunately, the Supreme Court did not commit itself to accepting the misappropriation theory in Carpenter. It is submitted that, by using the rationale behind the acceptance of fraud on the market in Basic, it is appropriate to overrule the fiduciary link requirement of Chiarolla. This suggests that a prohibition of cross insider irading can easily be based on the traditional "disclose or abstain" legal theory, a more satisfactory interpretation of Rule 10b-5 than the misappropriation theory. 